\title{
Revealing the Effect of Phase Composition and Transformation on the Mechanical Properties of a Cu-6Ni-6Sn-0.6Si Alloy
}

\author{
Zhuanqin Liang ${ }^{1}$, Wenxin Fan ${ }^{1}$, Pengfei Wang ${ }^{1, *}$, Yushuai Wang ${ }^{2, *}$, Kai Zhang ${ }^{1}$, Junsheng Zhao ${ }^{1}$ \\ and Lijun Peng ${ }^{3,4}$ \\ 1 School of Mechanical Engineering, North University of China, Taiyuan 030051, China; \\ zhuanqinliang@gmail.com (Z.L.); fanwx@nuc.edu.cn (W.F.); zhangk950417@gmail.com (K.Z.); \\ zjs@nuc.edu.cn (J.Z.) \\ 2 School of Mechanical \& Electrical Engineering, North University of China, Taiyuan 030051, China \\ 3 State Key Laboratory of Nonferrous Metals and Process, GRIMAT Group Co., Ltd., Beijing 100088, China; \\ penglijun198677@163.com \\ 4 GRIMAT Engineering Institute Co., Ltd., Beijing 101407, China \\ * Correspondence: wangpf20210001@nuc.edu.cn (P.W.); wangys@nuc.edu.cn (Y.W.)
}

Citation: Liang, Z.; Fan, W.; Wang, P.; Wang, Y.; Zhang, K.; Zhao, J.; Peng, L. Revealing the Effect of Phase

Composition and Transformation on the Mechanical Properties of a Cu-6Ni-6Sn-0.6Si Alloy. Materials 2021, 14, 5201. https://doi.org/ $10.3390 /$ ma14185201

Academic Editor: Jana Bidulská

Received: 9 August 2021

Accepted: 6 September 2021

Published: 10 September 2021

Publisher's Note: MDPI stays neutral with regard to jurisdictional claims in published maps and institutional affiliations.

Copyright: (C) 2021 by the authors Licensee MDPI, Basel, Switzerland. This article is an open access article distributed under the terms and conditions of the Creative Commons Attribution (CC BY) license (https:/ / creativecommons.org/licenses/by/ $4.0 /)$.

\begin{abstract}
In the present study, a Cu-6Ni-6Sn-0.6Si alloy is fabricated through frequency induction melting, then subjected to solution treatment, rolling, and annealing. The phase composition, microstructure evolution, and transition mechanism of the $\mathrm{Cu}-6 \mathrm{Ni}-6 \mathrm{Sn}-0.6 \mathrm{Si}$ alloy are researched systematically through simulation calculation and experimental characterization. The ultimate as-annealed sample simultaneously performs with high strength and good ductility according to the uniaxial tensile test results at room temperature. There are amounts of precipitates generated, which are identified as belonging to the DO22 and L12 phases through the transmission electron microscope (TEM) analysis. The DO22 and L12 phase precipitates have a significant strengthening effect. Meanwhile, the generation of the common discontinuous precipitation of the $\gamma$ phase, which is harmful to the mechanical properties of the copper-nickel-tin alloy, is inhibited mightily during the annealing process, possibly due to the existence of the Ni5Si2 primary phase. Therefore, the as-annealed sample of the $\mathrm{Cu}-6 \mathrm{Ni}-6 \mathrm{Sn}-0.6 \mathrm{Si}$ alloy possesses high tensile strength and elongation, which are $967 \mathrm{MPa}$ and $12 \%$, respectively.
\end{abstract}

Keywords: copper-nickel-tin alloy; primary phase; precipitates; solution treatment; annealing; mechanical properties

\section{Introduction}

The copper-nickel-tin alloy is one of the important copper alloys that is widely used in modern industries such as aerospace, rail transit, heavy-duty machinery, marine engineering, etc. [1-7] In recent years, many researchers have been attracted to the study of how to improve the mechanical properties and conductivity of copper-nickel-tin alloys such as $\mathrm{Cu}-15 \mathrm{Ni}-8 \mathrm{Sn}$ [8-10] and $\mathrm{Cu}-9 \mathrm{Ni}-6 \mathrm{Sn}$, with high contents of $\mathrm{Ni}$ and $\mathrm{Sn}$ elements $[11,12]$. It is well known that the mechanical properties depend on the microstructures; thus, the microstructure evolution and influencing factors should be researched systematically. Alloying elements added into the copper-nickel-tin alloys can affect the microstructures of the alloys, causing the mechanical properties of the alloys to vary [13-21]. A lot of research shows that the segregation suppression of Sn during the solidification process and the inhibition of the discontinuous precipitation of the $\gamma$ phase during the heat treatment process are two difficulties which can directly influence their comprehensive performance and application in copper-nickel-tin alloys with high $\mathrm{Ni}$ and $\mathrm{Sn}$ contents [22-26]. In particular, the generation of the discontinuous precipitation of the $\gamma$ phase can seriously impact the strength and ductility of copper-nickel-tin alloys such as $\mathrm{Cu}-15 \mathrm{Ni}-8 \mathrm{Sn}$ and $\mathrm{Cu}-$ 9Ni-6Sn $[27,28]$. The method of adding alloying elements such as V, Si, Cr, etc., has been 
used to solve the abovementioned difficulties for $\mathrm{Cu}-15 \mathrm{Ni}-8 \mathrm{Sn}$ and $\mathrm{Cu}-9 \mathrm{Ni}-6 \mathrm{Sn}$ [29-32]. However, the effect of alloying elements on the microstructures and mechanical properties of copper-nickel-tin alloys with low amounts of $\mathrm{Ni}$ and $\mathrm{Sn}$ added, such as $\mathrm{Cu}-6 \mathrm{Ni}-6 \mathrm{Sn}$, should also be studied, but has seldom been researched so far.

As one kind of typical copper-nickel-tin alloy, the mechanical properties of $\mathrm{Cu}-6 \mathrm{Ni}$ $6 \mathrm{Sn}$ is also reduced by the generation of the discontinuous precipitation of the $\gamma$ phase. Therefore, avoiding numerous generations of the discontinuous precipitation of the $\gamma$ phase in the $\mathrm{Cu}-6 \mathrm{Ni}-6 \mathrm{Sn}$ alloy would significantly improve its mechanical properties. At the same time, the microstructure evolution and phase composition of the $\mathrm{Cu}-6 \mathrm{Ni}-6 \mathrm{Sn}$ alloy should be researched systematically. Whether the microstructures and mechanical properties can be improved through additional alloying elements should be considered, and the element type and content should also be explored.

In the present study, $\mathrm{Si}$ is selected as the alloying element and added into $\mathrm{Cu}-6 \mathrm{Ni}-$ $6 \mathrm{Sn}$ to fabricate the $\mathrm{Cu}-6 \mathrm{Ni}-6 \mathrm{Sn}-0.6 \mathrm{Si}$ alloy; it is then subjected to solution treatment, rolling, and annealing. The phase composition, microstructure evolution, and mechanical properties of the $\mathrm{Cu}-6 \mathrm{Ni}-6 \mathrm{Sn}-0.6 \mathrm{Si}$ alloy during the whole process are observed and tested; relative mechanism is also analyzed and discussed. We propose a feasible and economical method, including composition design guidelines, temperature selection of the heat treatment principle, and a technical route for rolling in the fabrication of $\mathrm{Cu}-6 \mathrm{Ni}-6 \mathrm{Sn}-$ $0.6 \mathrm{Si}$, which can simultaneously perform with high strength and good ductility. This may even provide important references for the preparation of copper-nickel-tin alloys.

\section{Experimental Method}

\subsection{Sample Preparation}

The $\mathrm{Cu}-6 \mathrm{Ni}-6 \mathrm{Sn}-0.6 \mathrm{Si}$ alloy was prepared through frequency induction melting. The electrolytic copper $(99.97 \mathrm{wt})$, pure nickel $(99.8 \mathrm{wt} \%)$, and pure tin $(99.9 \mathrm{wt} \%)$ were melted in the furnace. Pure silicon $(99.9 \mathrm{wt} \%$ ) was added into the melt as the temperature reached $1300{ }^{\circ} \mathrm{C}$ and was maintained for $10 \mathrm{~min}$ to ensure the adequate melting of the Si elements. Then, the melt was poured into a steel mold with a $100 \mathrm{~mm}$ diameter and preheated to a temperature of $300{ }^{\circ} \mathrm{C}$. The ingot of the $\mathrm{Cu}-6 \mathrm{Ni}-6 \mathrm{Sn}-0.6 \mathrm{Si}$ alloy is shown in Figure 1 . The composition of the as-cast ingot was analyzed by $\mathrm{X}$-ray fluorescence spectrum technique (XRF) and is listed in Table 1. A sample with a dimension of $20 \times 15 \times 10 \mathrm{~mm}^{3}$ was cut form the ingot; then, the sample was hot-rolled with $50 \%$ deformation, followed by a solution treatment at $850^{\circ} \mathrm{C}$ for $6 \mathrm{~h}$. Finally, the solution-treated sample was subjected to room temperature rolling with $30 \%$ deformation and followed by annealing at $350{ }^{\circ} \mathrm{C}$ for $2 \mathrm{~h}$. The deformation amount was calculated by the formula $(\mathrm{d} 0-\mathrm{d}) / \mathrm{d} 0 \times 100 \%$, where $\mathrm{d} 0$ and $\mathrm{d}$ are the initial and ultimate thickness of the rolling sample, respectively.

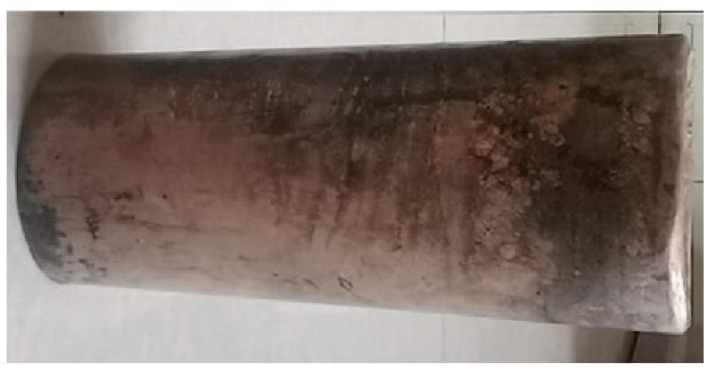

Figure 1. The ingot of the $\mathrm{Cu}-6 \mathrm{Ni}-6 \mathrm{Sn}-0.6 \mathrm{Si}$ alloy.

Table 1. The chemical composition of the $\mathrm{Cu}-6 \mathrm{Ni}-6 \mathrm{Sn}-0.6 \mathrm{Si}$ alloy.

\begin{tabular}{ccccc}
\hline Element & Ni & Sn & Si & Cu \\
\hline Wt $(\%)$ & 6.12 & 5.86 & 0.61 & Balance \\
\hline
\end{tabular}




\subsection{Microstructure Analysis}

The optical microscope (OM; Olympus BX51, Kyoto, Japan) and scanning electron microscope (SEM; Zeiss Supra55, Baden-Wurttemberg, Germany) were used to observe the microstructures of as-cast, solution-treated, as-rolled, and as-annealed samples of the $\mathrm{Cu}-6 \mathrm{Ni}-6 \mathrm{Sn}-0.6 \mathrm{Si}$ alloy. Samples for OM and SEM observation were ground with sandpaper, followed by mechanical polishing. For this paper, the scanning electron microscope secondary electron imaging technology was used, with a voltage of $10 \mathrm{kV}$, while the voltage of the energy dispersive spectrometer (EDS, JEOL JSM-5600LV, Kyoto, Japan) was $15 \mathrm{kV}$. Then, they were etched in a solution containing $2 \mathrm{~mL}$ hydrochloric acid, $96 \mathrm{~mL}$ alcohol, and $3 \mathrm{~g} \mathrm{FeCl}_{3}$. Further microstructure research was conducted; the as-cast, solution-treated, and as-annealed samples were observed and analyzed by transmission electron microscope (TEM; Philips Tecnai-G ${ }^{2}$, Amsterdam, The Netherlands). The samples for TEM observation were thinned down to $50 \mu \mathrm{m}$ through mechanical grinding to obtain thin foils; then, disc samples with a $3 \mathrm{~mm}$ diameter were punched out from the thin foils. Ultimately, disc samples were electro-polished, which was performed at about $-40{ }^{\circ} \mathrm{C}$ in a solution containing methanol and nitric acid (with a volume ratio of 3:1) using a twin-jet electropolisher, at the voltage of $10 \mathrm{v}$. The simulation pseudo-binary phase diagram of the $\mathrm{Cu}-6 \mathrm{Ni}-6 \mathrm{Sn}-\mathrm{xSi}$ alloy was calculated through the thermodynamic simulation software Pandat to further analyze the microstructure evolution, including the existing and transition form of the Si-rich phase of the $\mathrm{Cu}-6 \mathrm{Ni}-6 \mathrm{Sn}-0.6 \mathrm{Si}$ alloy.

\subsection{Mechanical Properties Test}

The mechanical properties of the as-rolled and as-annealed samples were measured by uniaxial tensile test at room temperature using the MTS Criterion C45 (Eden Prairie, Minnesota, MN, USA) testing machine. A schematic diagram of the tensile specimens and their dimensions are shown in Figure 2. Five samples were tested to ensure the credibility and reproducibility of the experimental results. The fracture morphology of the tensile sample after the tensile test was observed through SEM.
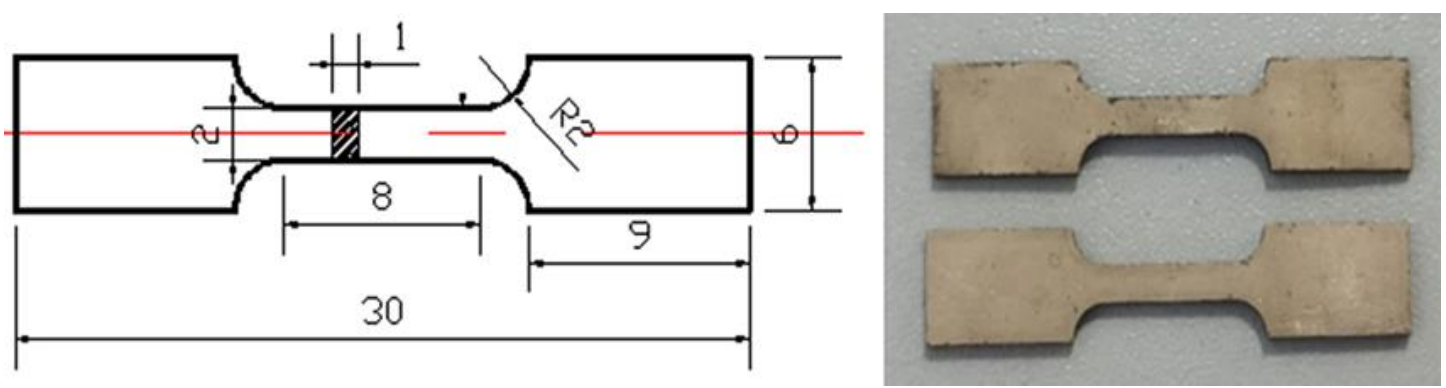

Figure 2. A schematic diagram of tensile specimens, with dimensions; tensile samples.

\section{Results}

\subsection{Microstructures of As-Cast Sample}

Figure 3 presents metallographic images and shows the microstructures of the ascast sample of the $\mathrm{Cu}-6 \mathrm{Ni}-6 \mathrm{Sn}-0.6 \mathrm{Si}$ alloy. It is evident that the as-cast sample of the $\mathrm{Cu}-6 \mathrm{Ni}-6 \mathrm{Sn}-0.6 \mathrm{Si}$ alloy contains blatant dendritic solidified microstructures with coarse dendrite, as seen in Figure 3a. In addition to the dendritic matrix, the metallographic image suggests that there seem to be two types of second phases-represented by the colors black and grey-distributed in the $\mathrm{Cu}-6 \mathrm{Ni}-6 \mathrm{Sn}-0.6 \mathrm{Si}$ alloy, as indicated by the red arrows in Figure $3 b$, which may suggest that the addition of the element $S i$ leads to the generation of second phases during the solidification process of the $\mathrm{Cu}-6 \mathrm{Ni}-6 \mathrm{Sn}-0.6 \mathrm{Si}$ alloy. 

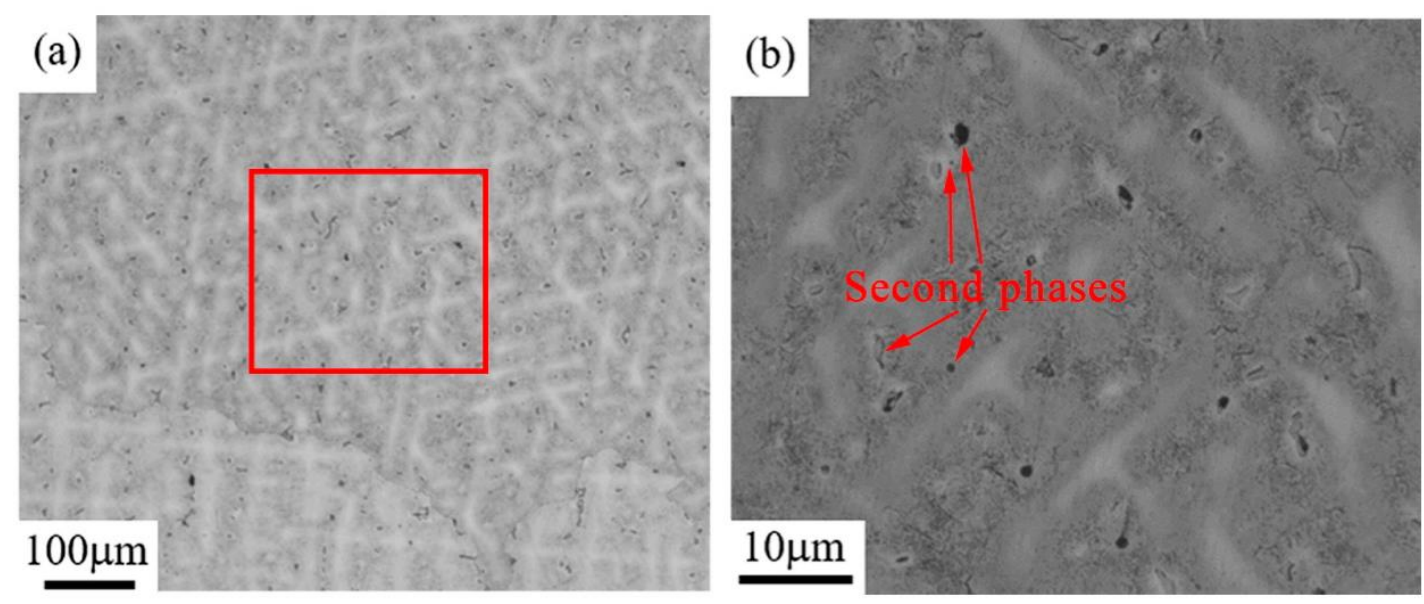

Figure 3. Metallographic images of the as-cast sample of the $\mathrm{Cu}-6 \mathrm{Ni}-6 \mathrm{Sn}-0.6 \mathrm{Si}$ alloy: (a) low magnification and (b) high magnification.

The second phases distributed in the matrix were further observed and analyzed through SEM and energy dispersive spectrometer (EDS). Figure 4 shows the typical SEM image and the EDS results of the as-cast sample of the $\mathrm{Cu}-6 \mathrm{Ni}-6 \mathrm{Sn}-0.6 \mathrm{Si}$ alloy. The SEM result is in accordance with that of the metallographic analysis; plenty of second phases can be seen in the as-cast sample of the $\mathrm{Cu}-6 \mathrm{Ni}-6 \mathrm{Sn}-0.6 \mathrm{Si}$ alloy, as shown in Figure 4a. The EDS results of point 1 show that the black second phase is rich in the elements $\mathrm{Ni}$ and $\mathrm{Si}$, and their atom rate is close to 5:2, as shown in Figure $4 \mathrm{~b}$. The grey second phase is rich in $\mathrm{Ni}$ and $\mathrm{Sn}$, as shown in Figure 4c, based on the EDS analysis of point 2, which is common for copper-nickel-tin alloys. Relatively, the composition of the $\mathrm{Cu}-6 \mathrm{Ni}-6 \mathrm{Sn}-0.6 \mathrm{Si}$ alloy matrix is rich in the elements $\mathrm{Cu}, \mathrm{Ni}$, and $\mathrm{Sn}$, but its $\mathrm{Si}$ content is poor, as indicated by the EDS analysis of point 3 shown in Figure $4 \mathrm{~d}$.

The element distribution state in the as-cast sample of the $\mathrm{Cu}-6 \mathrm{Ni}-6 \mathrm{Sn}-0.6 \mathrm{Si}$ alloy is shown in Figure 5. For the black second phase, an obvious segregation of $\mathrm{Ni}$ and $\mathrm{Si}$ can be observed in the EDS mapping image. Meanwhile, the grey second phase is rich in the elements $\mathrm{Ni}$ and $\mathrm{Sn}$, as seen in Figure 5. These also confirm that the addition of Si exists mainly in one of the forms of the Si-rich phase in the as-cast sample of the $\mathrm{Cu}-6 \mathrm{Ni}-6 \mathrm{Sn}-0.6 \mathrm{Si}$ alloy. However, the Si content is poor in the matrix.

To further determine the type of the Ni-Si second phase in the as-cast sample of the Cu-6Ni-6Sn-0.6Si alloy, the sample was subjected to TEM observation. The bright-field image, dark-field image, selected-area electron diffraction, high-resolution image, and Fourier transform of the Ni-Si-rich phase in the as-cast sample of the $\mathrm{Cu}-6 \mathrm{Ni}-6 \mathrm{Sn}-0.6 \mathrm{Si}$ alloy are shown in Figure 6. Combined with the SEM results, the phase which is rich in $\mathrm{Ni}$ and $\mathrm{Si}$ in the as-cast sample of the $\mathrm{Cu}-6 \mathrm{Ni}-6 \mathrm{Sn}-0.6 \mathrm{Si}$ alloy is $\mathrm{Ni}_{5} \mathrm{Si}_{2}$.

In conclusion, there are many second phases distributed in the as-cast sample of the Cu-6Ni-6Sn-0.6Si alloy according to the metallographic, SEM, and EDS analyses. One of the second phases is $\mathrm{Ni}_{5} \mathrm{Si}_{2}$, the other one is the common $\gamma$-phase in the $\mathrm{Cu}-\mathrm{Ni}$-Sn alloys. The addition of the element $\mathrm{Si}$ exists in the $\mathrm{Cu}-6 \mathrm{Ni}-6 \mathrm{Sn}-0.6 \mathrm{Si}$ alloy mainly in the form of the Si-rich phase, while the remaining is dissolved as a solid-solution atom in the matrix. 

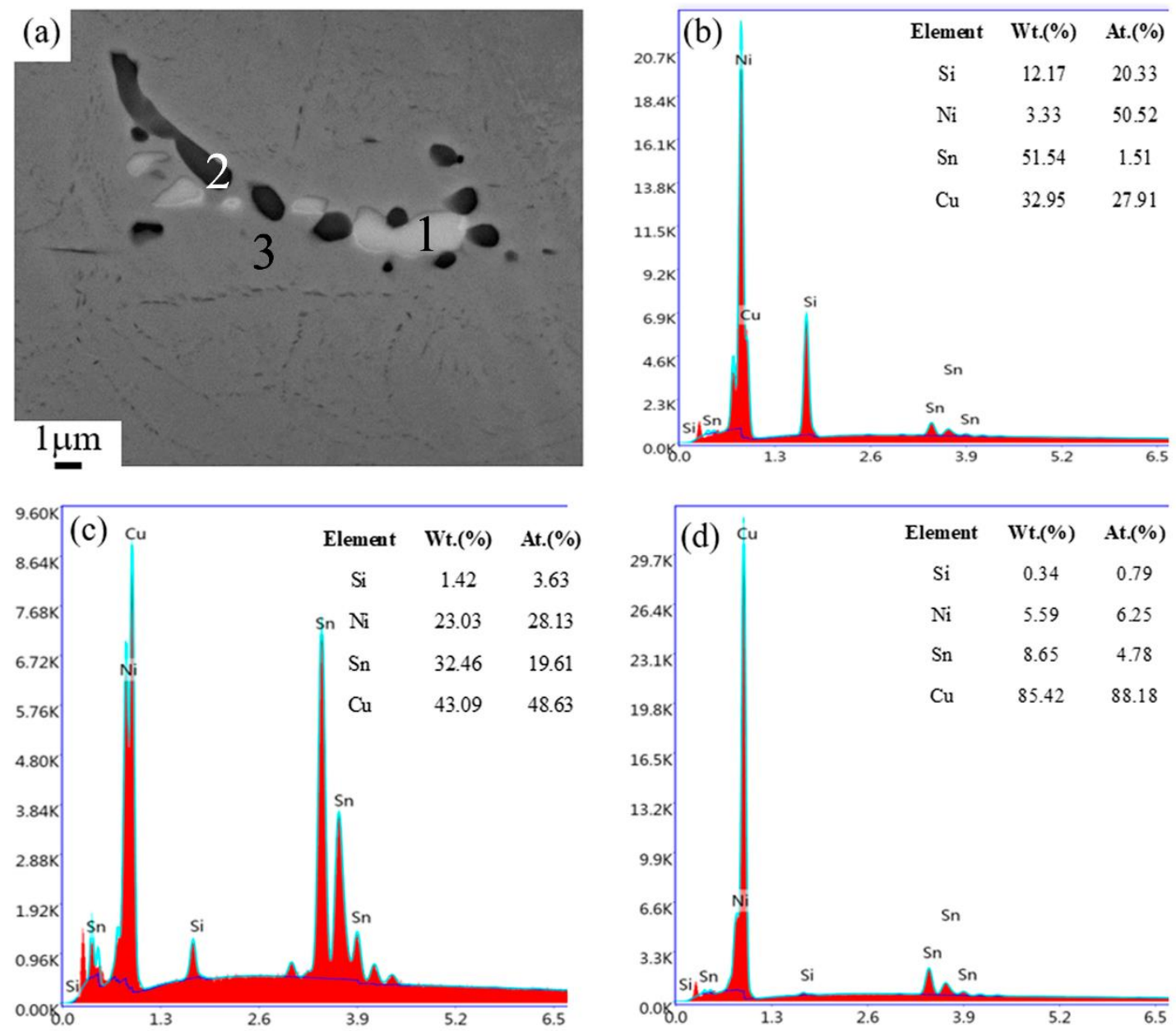

Figure 4. The SEM images (a) and EDS results of the as-cast sample of the Cu-6Ni-6Sn-0.6Si alloy: (b) point 1, (c) point 2, (d) point 3 .
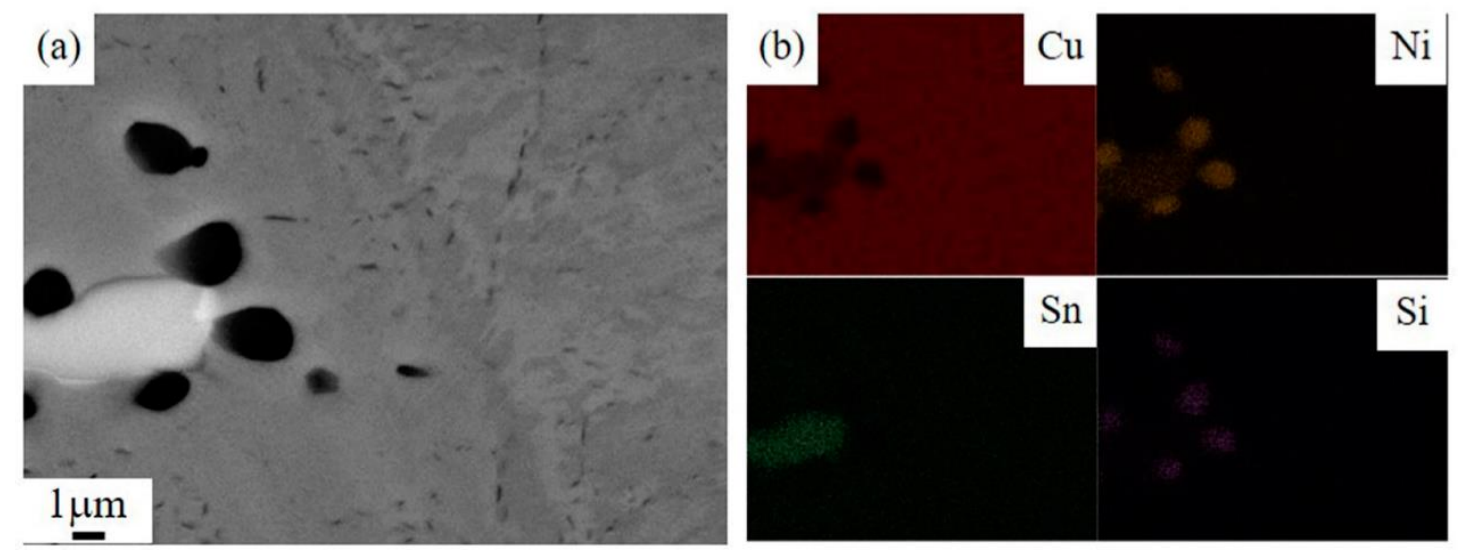

Figure 5. The element distribution state of the as-cast sample of the $\mathrm{Cu}-6 \mathrm{Ni}-6 \mathrm{Sn}-0.6 \mathrm{Si}$ alloy: (a) image of particles, (b) EDS-mapping of $\mathrm{Cu}, \mathrm{Ni}$, Sn, Si element. 

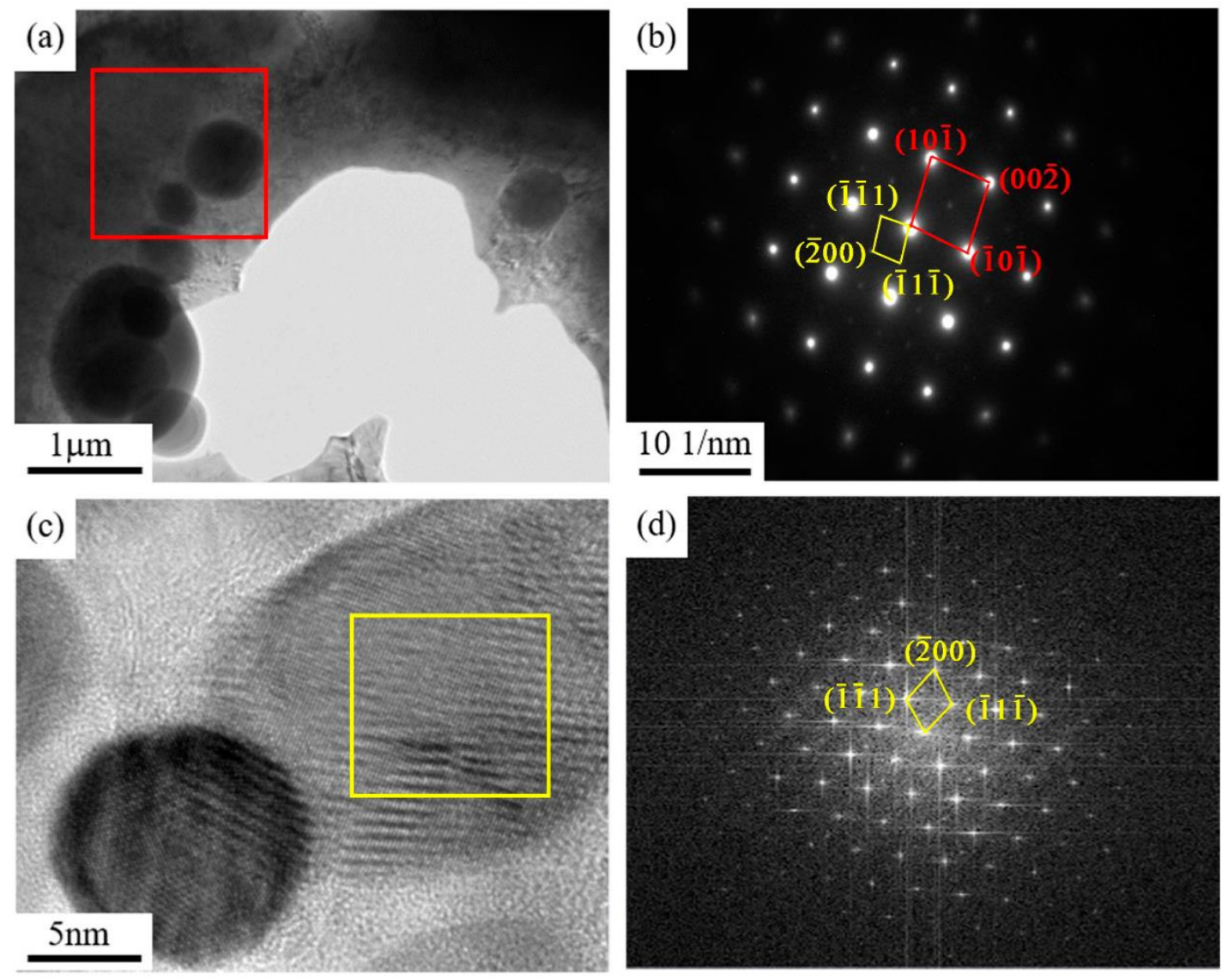

Figure 6. TEM images and analysis of the Cu-6Ni-6Sn-0.6Si alloy: (a) bright-field image, (b) dark-field image, (c) selectedarea electron diffraction, (d) high-resolution image and Fourier transform.

\subsection{Microstructures of Solution-Treated Sample}

The microstructures of the $\mathrm{Cu}-6 \mathrm{Ni}-6 \mathrm{Sn}-0.6 \mathrm{Si}$ alloy after solution treatment at $850{ }^{\circ} \mathrm{C}$ for $6 \mathrm{~h}$ was observed and analyzed. Figure 7 shows metallographic images of the solutiontreated sample of the $\mathrm{Cu}-6 \mathrm{Ni}-6 \mathrm{Sn}-0.6 \mathrm{Si}$ alloy. As shown in Figure 7a, the dendrites disappear and coarse equiaxed grains are dominant in the solution-treated sample. Meanwhile, one type of second phase is clearly visible, as indicated by the red arrows in Figure 7b. Therefore, there are still many second phases in the $\mathrm{Cu}-6 \mathrm{Ni}-6 \mathrm{Sn}-0.6 \mathrm{Si}$ alloy after solution treatment.

Figure 8 shows the SEM images and EDS analysis of the solution-treated sample of the $\mathrm{Cu}-6 \mathrm{Ni}-6 \mathrm{Sn}-0.6 \mathrm{Si}$ alloy. There are evident second phases in the $\mathrm{Cu}-6 \mathrm{Ni}-6 \mathrm{Sn}-0.6 \mathrm{Si}$ alloy, as shown in Figure 8a, which is in agreement with the results of the metallographic analysis. Meanwhile, the EDS result suggests that all of the second phases are still rich in $\mathrm{Ni}$ and $\mathrm{Si}$, whose atom rates are still approximately 5:2, as shown in Figure 8b-d. This may illustrate that this type of second phase in the solution-treated sample is the same as that of the as-cast sample in the $\mathrm{Cu}-6 \mathrm{Ni}-6 \mathrm{Sn}-0.6 \mathrm{Si}$ alloy. In other words, this type of second phase cannot be dissolved into the matrix through solution treatment. However, the Sn-rich phases in the as-cast sample have disappeared, which means that these types of second phases are dissolved into the matrix after solution treatment. 
(a)

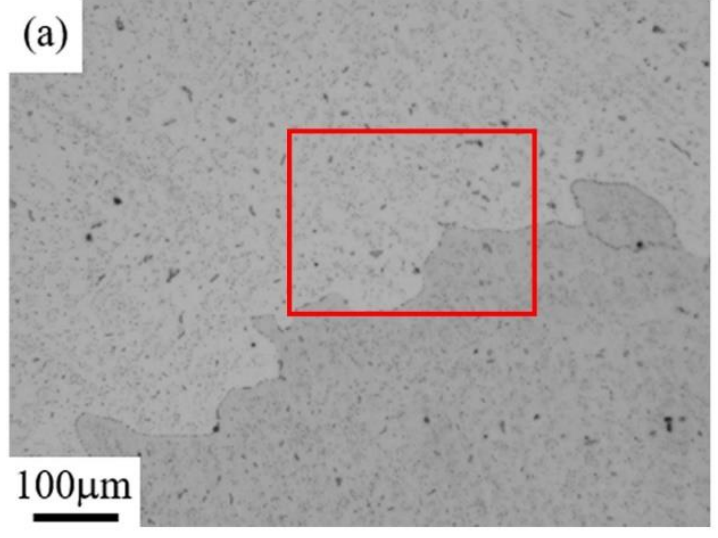

(b)

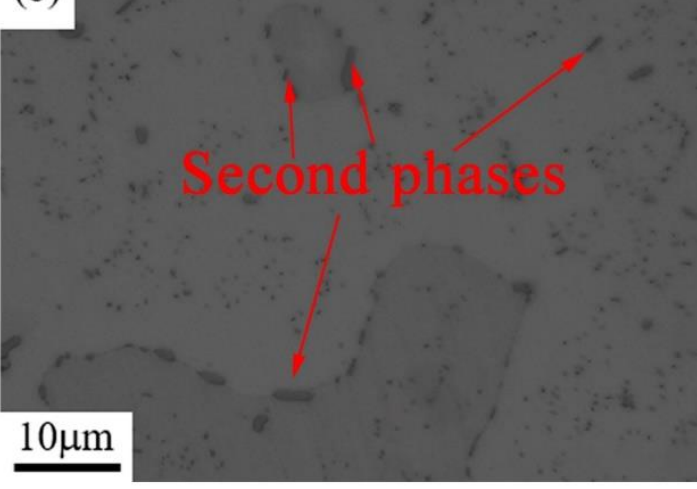

Figure 7. Metallographic images of the solution-treated sample of the $\mathrm{Cu}-6 \mathrm{Ni}-6 \mathrm{Sn}-0.6 \mathrm{Si}$ alloy: (a) low magnification and (b) high magnification.
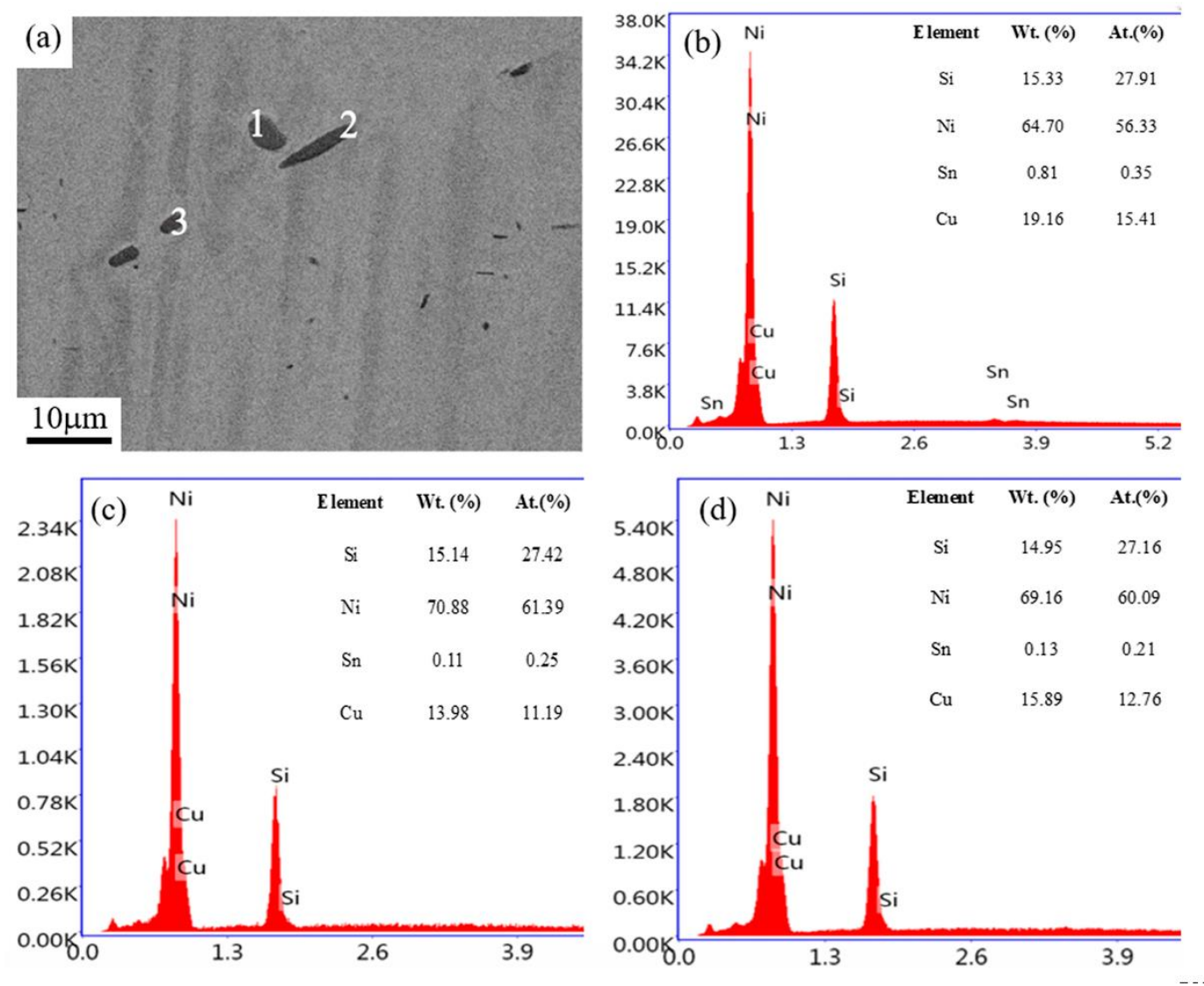

Figure 8. The SEM images (a) and EDS results of the as-cast sample of the Cu-6Ni-6Sn-0.6Si alloy: (b) point 1 (c) point 2 (d) point 3.

Figure 9 presents the TEM images of the solution-treated sample of the $\mathrm{Cu}-6 \mathrm{Ni}-6 \mathrm{Sn}-$ $0.6 \mathrm{Si}$ alloy. The Si-rich phase is distributed in the matrix, as indicated by red arrows in Figure $9 \mathrm{a}$. These $\mathrm{Si}$-rich phases are $\mathrm{Ni}_{5} \mathrm{Si}_{2}$ according to the selected-area electron diffraction, high-resolution image, and Fourier transform, as shown in Figure 9b-d. 

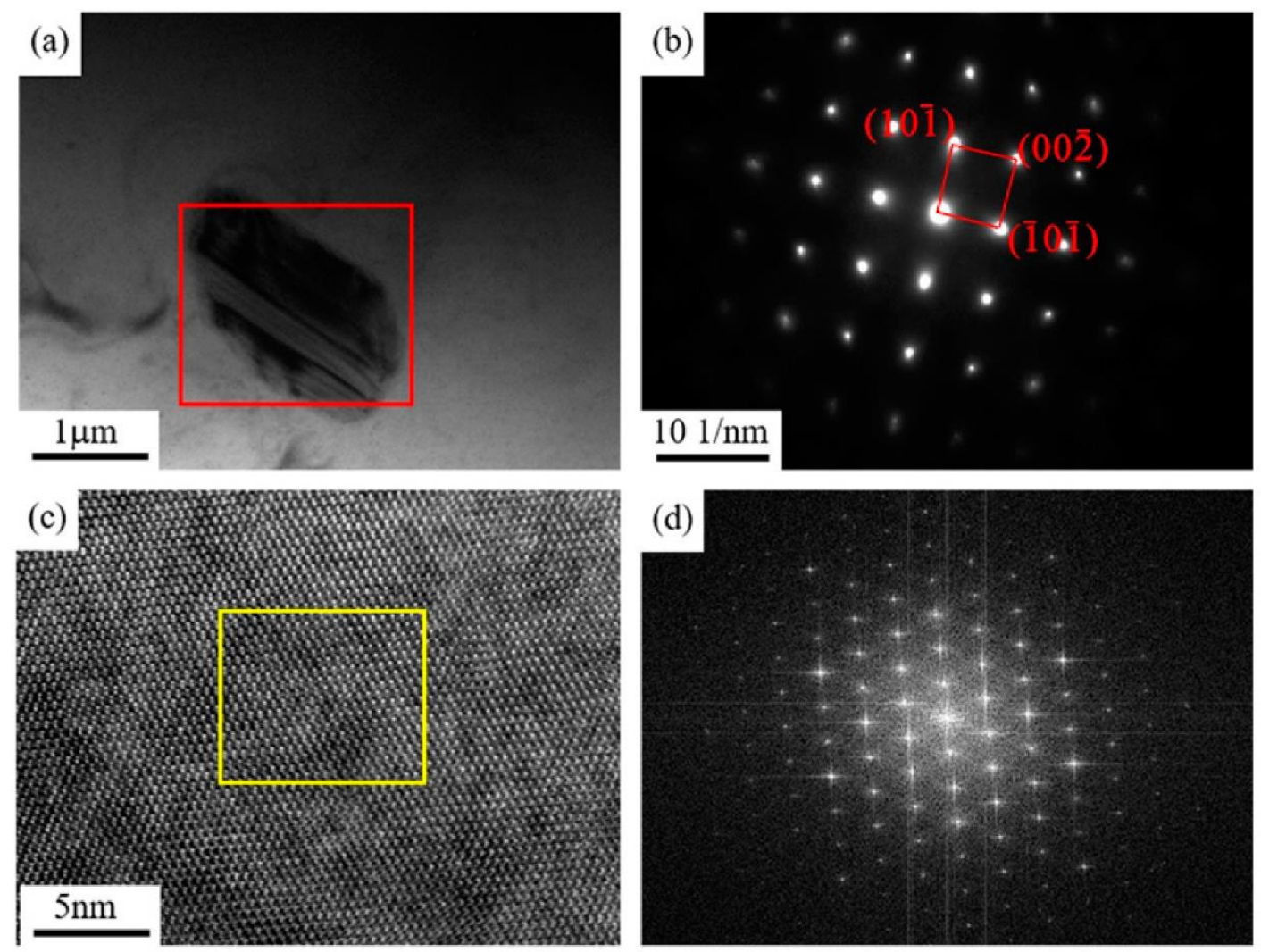

Figure 9. The TEM images of the solution-treated sample of the $\mathrm{Cu}-6 \mathrm{Ni}-6 \mathrm{Sn}-0.6 \mathrm{Si}$ alloy: (a) bright-field image, (b) selectedarea electron diffraction, (c) high-resolution image, (d) Fourier transform.

Therefore, the Si-rich phase cannot be dissolved into the matrix through solution treatment for the $\mathrm{Cu}-6 \mathrm{Ni}-6 \mathrm{Sn}-0.6 \mathrm{Si}$ alloy. Moreover, the second phase of the Si-rich phases, both in the as-cast and solution-treated samples, are the $\mathrm{Ni}_{5} \mathrm{Si}_{2}$ phase. However, the $\mathrm{Sn}$-rich phases can be dissolved into the matrix. The phase composition of the as-cast sample include the matrix, $\mathrm{Ni}_{5} \mathrm{Si}_{2}$, and $\mathrm{Sn}$-rich phases, but the phase composition of the solutiontreated sample include the matrix and $\mathrm{Ni}_{5} \mathrm{Si}_{2}$ phases according to the analysis above.

\subsection{Microstructures of As-Annealed Samples}

The solution-treated sample of the $\mathrm{Cu}-6 \mathrm{Ni}-6 \mathrm{Sn}-0.6 \mathrm{Si}$ alloy is rolled at room temperature with $30 \%$ deformation and followed by annealing at $350{ }^{\circ} \mathrm{C}$ for $2 \mathrm{~h}$. It is well-known that no phase transition occurs during the room temperature rolling process, except for the dislocation accumulation; therefore, it is unnecessary to observe and analyze the microstructures of as-rolled samples. Figure 10 shows the TEM analysis of the as-annealed sample. It is obvious that there are numerous fine phases that can be observed in the brightfield image, as shown in Figure 10a. Selected-area electron diffraction, high-resolution, and Fourier transform suggest that the phases are $\mathrm{DO}_{22}$ and $\mathrm{L}_{12}$ precipitates. There is also no visible discontinuous precipitation of the $\gamma$ phase that can be observed in the sample. It was observed that there were numerous $\mathrm{DO}_{22}$ and $\mathrm{L}_{12}$ precipitates generated during the annealing process, and the generation of the discontinuous precipitation of the $\gamma$ phase was inhibited. 

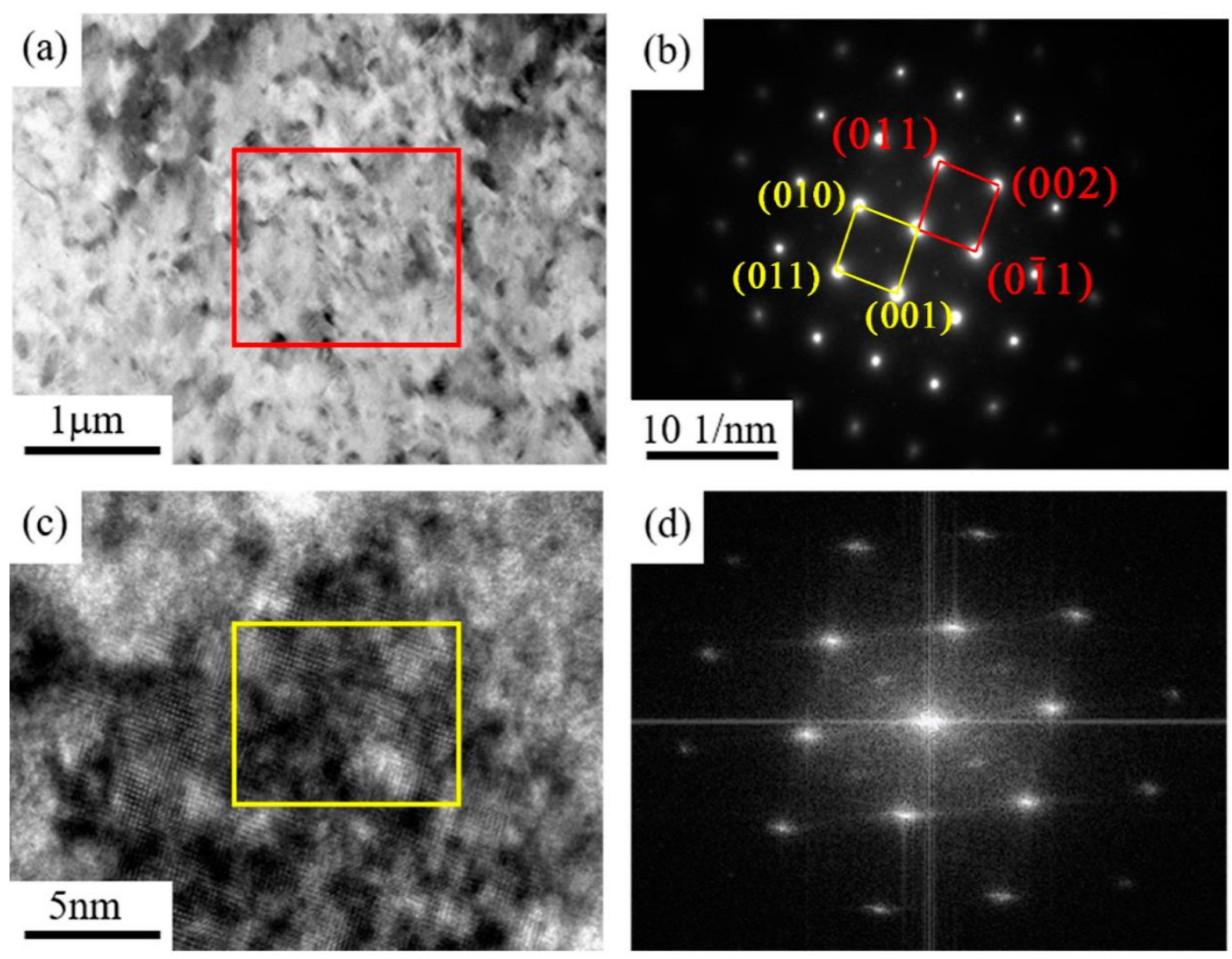

Figure 10. The microstructures of the as-annealed sample of the $\mathrm{Cu}-6 \mathrm{Ni}-6 \mathrm{Sn}-0.6 \mathrm{Si}$ alloy: (a) metallographic images, (b) SEM image, (c) TEM image, (d) EDS analysis.

\subsection{Mechanical Properties of the $\mathrm{Cu}-6 \mathrm{Ni}-6 \mathrm{Sn}-0.6 \mathrm{Si}$ Alloy}

Figure 11 shows the typical tensile curves of the as-rolled and as-annealed samples of $\mathrm{Cu}-6 \mathrm{Ni}-6 \mathrm{Sn}-0.6 \mathrm{Si}$ alloys; the average values of tensile strength and elongation are listed in Table 2. It can be seen that the average tensile strength of the as-annealed sample increases more significantly compared with the as-rolled sample, which reaches $967 \mathrm{MPa}$ and $729 \mathrm{MPa}$, respectively. Meanwhile, the ductility of the as-annealed sample is also better than that of the as-rolled sample, whose average elongation are $12 \%$ and $7 \%$, respectively.

Figure 12 shows the fracture morphology of the sample after tensile test. There are limited and shallow dimples evident in the as-rolled sample shown in Figure 12a. There are numerous and fine dimples that are deep and distinctly present in the as-annealed sample, as indicated in Figure 12b. 


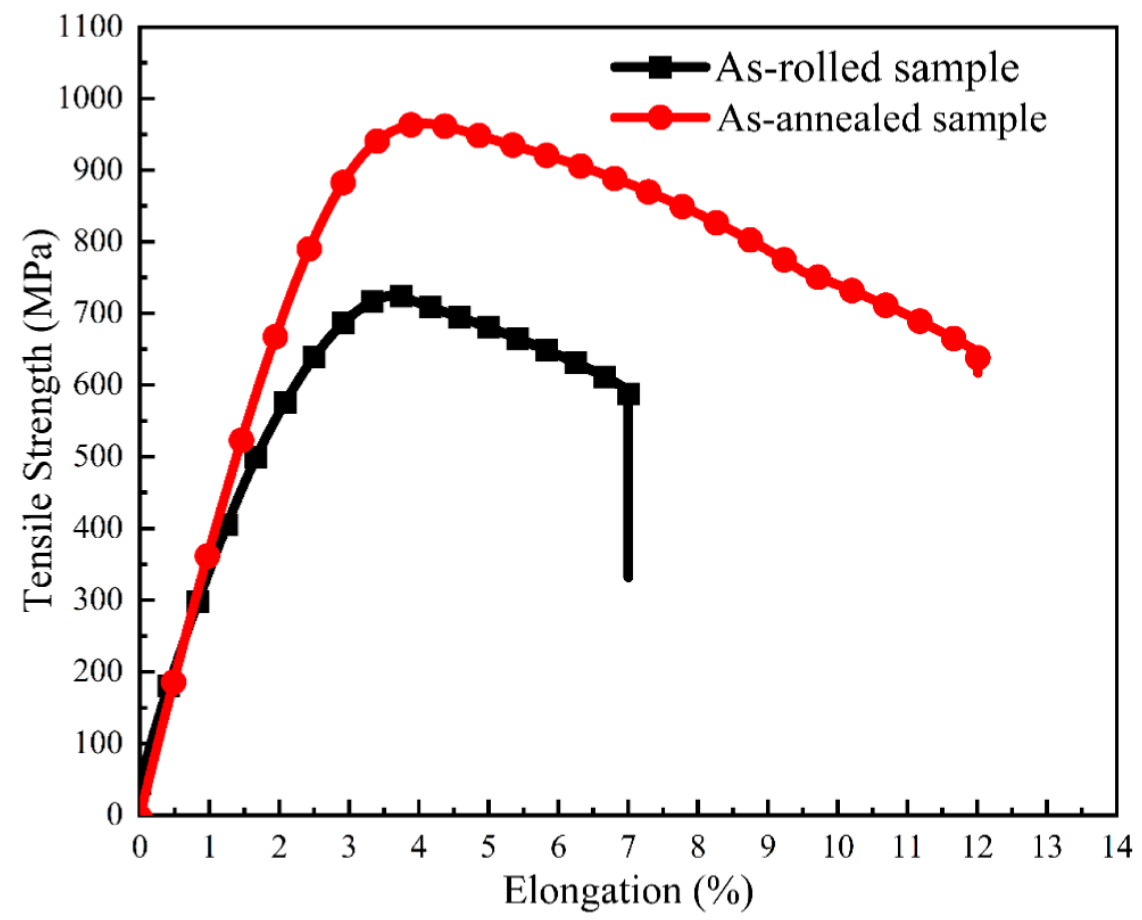

Figure 11. The typical tensile curve of solution-treated and as-annealed samples of the $\mathrm{Cu}-6 \mathrm{Ni}-6 \mathrm{Sn}-$ $0.6 \mathrm{Si}$ alloy.

Table 2. Average tensile properties of Cu-6Ni-6Sn-0.6Si alloy.

\begin{tabular}{ccc}
\hline Tensile Properties & As-Rolled & As-Annealed \\
\hline Tensile strength $(\mathrm{MPa})$ & 725 & 965 \\
Elongation $(\%)$ & 7 & 12 \\
\hline
\end{tabular}
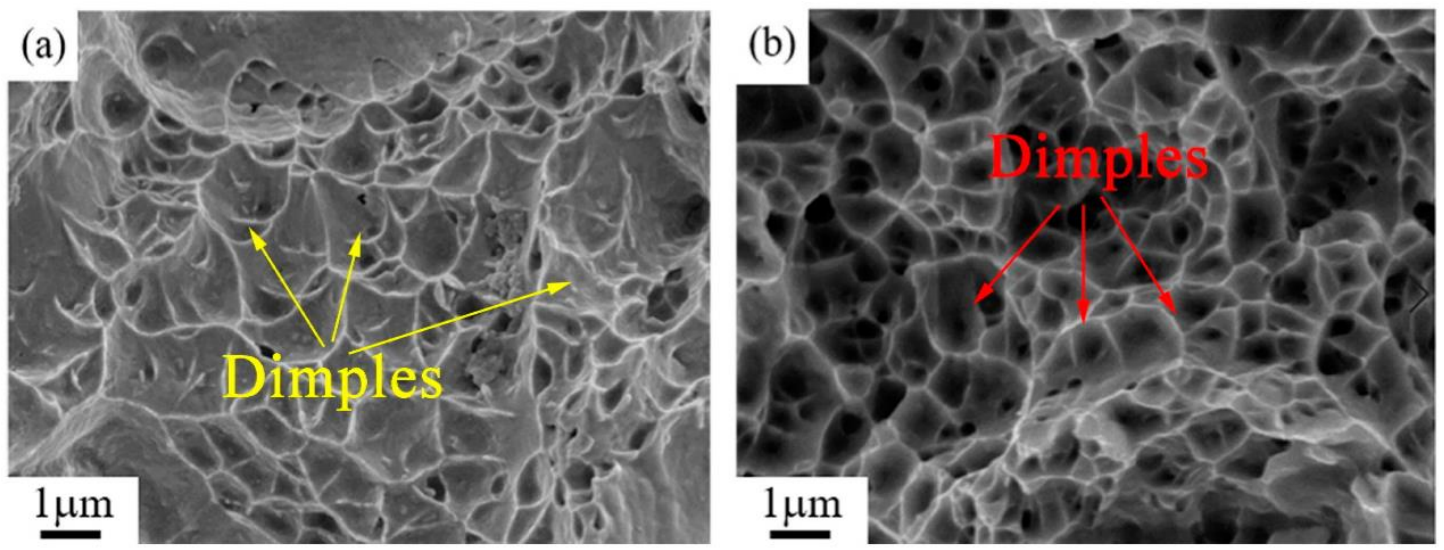

Figure 12. Fracture morphology of tensile samples: (a) solution-treated sample, (b) as-annealed sample.

\section{Discussion}

\subsection{Phase Composition and Transformation of the $\mathrm{Cu}-6 \mathrm{Ni}-6 \mathrm{Sn}-0.6 \mathrm{Si}$ Alloy}

Figure 13 is the simulation-calculated pseudo-binary phase diagram of $\mathrm{Cu}-6 \mathrm{Ni}-6 \mathrm{Sn}-$ $\mathrm{xSi}$ alloys. The pseudo-binary phase diagram of the $\mathrm{Cu}-6 \mathrm{Ni}-6 \mathrm{Sn}-\mathrm{xSi}$ alloy indicates that the primary phase generates at an elevated temperature, as shown in Figure 13, and the primary phase is $\mathrm{Ni}_{5} \mathrm{Si}_{2}$. However, this is only if the sample is remelted; otherwise, the $\mathrm{Ni}_{5} \mathrm{Si}_{2}$ primary phase cannot be eliminated. This means that the primary $\mathrm{Ni}_{5} \mathrm{Si}_{2}$ cannot be 
dissolved into the matrix after solution treatment, which is identical with the results of the microstructure analysis through metallographic, SEM, and TEM. Owning to the existence of the $\mathrm{Ni}_{5} \mathrm{Si}_{2}$ primary phase, the generation of the discontinuous precipitation of the $\gamma$ phase that is harmful to the mechanical properties will be restrained; after this, numerous $\mathrm{DO}_{22}$ and $\mathrm{L}_{12}$ precipitates, which can significantly improve the mechanical properties, generate during the annealing process. It seems that the dislocation accumulation caused by room-temperature rolling also provides positions and promotes the generation of $\mathrm{DO}_{22}$ and $\mathrm{L}_{12}$ precipitates [33,34]. Additionally, the mechanical properties of the $\mathrm{Cu}-6 \mathrm{Ni}-6 \mathrm{Sn}-$ $0.6 \mathrm{Si}$ alloy are evidently increased after annealing. The fracture morphology observation results may suggest that the existence of dispersive and fine $\mathrm{DO}_{22}$ and $\mathrm{L}_{12}$ precipitates lead to the fine, numerous, and deep dimples of the tensile test sample. Therefore, the phase compositions of the as-cast sample are the $\alpha$-Cu matrix, $\mathrm{Ni}_{5} \mathrm{Si}_{2}$ primary phase, and $\mathrm{Sn}$-rich phase. The $\mathrm{Sn}$-rich phase is dissolved into the matrix, but $\mathrm{Ni}_{5} \mathrm{Si}_{2}$ primary phase still exists after hot rolling followed by solution treatment. Subsequently, $\mathrm{DO}_{22}$ and $\mathrm{L}_{12}$ precipitates are generated during the annealing process, and the phase compositions of the as-annealed sample are the $\alpha$-Cu matrix, $\mathrm{Ni}_{5} \mathrm{Si}_{2}$ primary phase, and the $\mathrm{DO}_{22}$ and $\mathrm{L}_{12}$ precipitates.

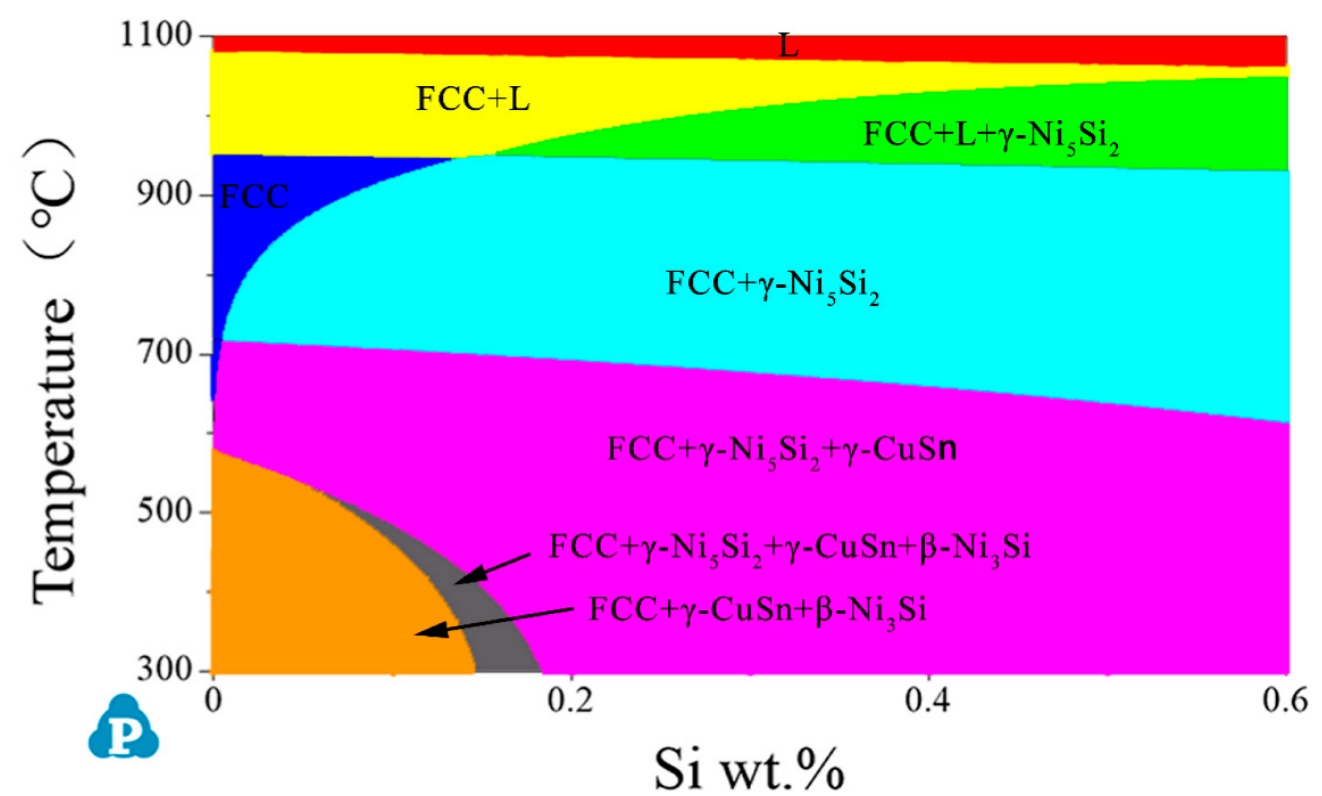

Figure 13. The simulation-calculated pseudo-binary phase diagram of the $\mathrm{Cu}-6 \mathrm{Ni}-6 \mathrm{Sn}-\mathrm{xSi}$ alloy.

\subsection{Mechanisms of the Mechanical Properties Variation of the As-Annealed Sample}

When the as-rolled sample is subjected to annealing, the tensile strength and ductility are improved simultaneously according to the tensile test. It is well known that the size and distribution status can significantly influence the strengthening effect of precipitates [35,36]. Moreover, it is widely accepted that the $\mathrm{DO}_{22}$ and $\mathrm{L}_{12}$ precipitates are favorable for the strength of the copper-nickel-tin alloys, but the discontinuous precipitation of the $\gamma$ phase can severely damage the strength of the copper-nickel-tin alloys [37]. There are several fine and diffused $\mathrm{DO}_{22}$ and $\mathrm{L}_{12}$ precipitates in the as-annealed sample, and no obvious discontinuous precipitation of the $\gamma$ phase can be observed. Therefore, the increasing strength of the as-annealed sample may mainly be caused by the generation and the dispersion of small $\mathrm{DO}_{22}$ and $\mathrm{L}_{12}$ precipitates. The ductility of the as-annealed sample is better than that of the as-rolled sample, which may also be attributed to the generation of $\mathrm{DO}_{22}$ and $\mathrm{L}_{12}$ precipitates. Due to the solution atoms, which are harmful to the ductility of the alloy precipitates $\mathrm{DO}_{22}$ and $\mathrm{L}_{12}$, lattice distortion is relieved. At the same time, dislocation accumulation, which can also damage the ductility, is recovered and the sample is softened after annealing. Hence, the as-annealed sample can perform with better ductility than that of the as-rolled sample. But for the as-rolled sample, there are no $\mathrm{DO}_{22}$ and $\mathrm{L}_{12}$ 
precipitates generated, and the hardening, which can reduce the ductility, is not eased. Hence, the as-rolled sample performs with relatively low strength and poor ductility.

\section{Conclusions}

A Cu-6Ni-6Sn-0.6Si alloy with excellent mechanical properties, simultaneously possessing high strength and good ductility, was obtained in the present study. The phase composition, microstructures evolution, and phase transition of as-cast, solution-treated, and as-annealed samples were researched. And the effect of phase composition and transformation on the mechanical properties of the $\mathrm{Cu}-6 \mathrm{Ni}-6 \mathrm{Sn}-0.6 \mathrm{Si}$ alloy was revealed. The main conclusions are presented as follows:

1. There are two types of second phases, which are the $\mathrm{Ni}_{5} \mathrm{Si}_{2}$ primary phase and the $\mathrm{Sn}$-rich phase in the as-cast sample of the $\mathrm{Cu}-6 \mathrm{Ni}-6 \mathrm{Sn}-0.6 \mathrm{Si}$ alloy. The $\mathrm{Ni}_{5} \mathrm{Si}_{2}$ primary phase cannot be dissolved into the matrix and still exists after hot rolling followed by solution treatment, but the Sn-rich phase disappears and dissolves into the matrix through hot rolling followed by solution treatment.

2. There are numerous $\mathrm{DO}_{22}$ and $\mathrm{L}_{12}$ precipitates in the as-annealed sample of the $\mathrm{Cu}$ $6 \mathrm{Ni}-6 \mathrm{SN}-0.6 \mathrm{Si}$ alloy. The generation of $\mathrm{DO}_{22}$ and $\mathrm{L}_{12}$ precipitates is promoted, but the generation of discontinuous precipitation of the $\gamma$ phase is prohibited severely during the annealing process.

3. The mechanical properties of as-annealed sample can be significantly improved compared with the as-rolled sample. High strength is mainly attributed to the existence of numerous $\mathrm{DO}_{22}$ and $\mathrm{L}_{12}$ precipitates. Good ductility can mainly be ascribed to the generation of $\mathrm{DO}_{22}$ and $\mathrm{L}_{12}$ precipitates and annealing softening.

Author Contributions: Conceptualization, Z.L. and K.Z.; methodology, P.W. and Y.W.; software, Z.L.; validation, K.Z., L.P. and P.W.; formal analysis, Y.W.; investigation, L.P.; resources, W.F.; data curation, P.W.; writing—original draft preparation, Z.L.; writing—review and editing, W.F. and Y.W.; visualization, P.W.; supervision, W.F.; project administration, J.Z.; funding acquisition, J.Z. All authors have read and agreed to the published version of the manuscript.

Funding: This research received no external funding.

Institutional Review Board Statement: Not applicable.

Informed Consent Statement: Not applicable.

Data Availability Statement: Data sharing is not applicable for this article.

Acknowledgments: This work was supported by the Key R\&D Program, International Science and Technology Cooperation Project of Shanxi Province (201903D421035). Moreover, the simulation presented in this paper was performed by Pandat software and released databases. The authors would like to express their gratitude to Compu Therm for providing the simulation tools.

Conflicts of Interest: The authors declare no conflict of interest.

\section{References}

1. Zhao, C.; Wang, Z.; Li, D.; Xie, M.; Kollo, L.; Luo, Z.; Zhang, W.; Prashanth, K.G. Comparison of additively manufacturing samples fabricated from pre-alloyed and mechanically mixed powders. J. Alloys Compd. 2020, 830, 154603. [CrossRef]

2. Zhang, Y.; Xiao, Z.; Zhao, Y.; Li, Z.; Xing, Y.; Zhou, K. Effect of thermo-mechanical treatments on corrosion behavior of Cu-15Ni-8Sn alloy in $3.5 \mathrm{wt} \% \mathrm{NaCl}$ solution. Mater. Chem. Phys. 2017, 199, 54-66. [CrossRef]

3. Kwo, P.Y.; Lacerda, M.A. After the Direct-acting Antivirals Are Gone, There Is Still Work to Be Done in the Liver. Gastroenterology 2016, 151, 582-584. [CrossRef]

4. Cribb, W.R.; Grensing, F.C. Spinodal copper alloy C72900-New high strength antifriction alloy system. Can. Metall. Quart. 2013, 50, 232-239. [CrossRef]

5. Cribb, W.R.; Gedeon, M.J.; Grensing, F.C. Performance Advances in Copper-Nickel-Tin Spinodal Alloys. Adv. Mater. Process 2013, 9, 20-25.

6. Caris, J.; Varadarajan, R.; Stephens, J.J.; Lewandowski, J.J. Microstructural effects on tension and fatigue behavior of Cu-15Ni-8Sn sheet. Mater. Sci. Eng. A 2008, 491, 137-146. [CrossRef] 
7. Singh, J.B.; Cai, W.; Bellon, P. Dry sliding of Cu-15 wt\% Ni-8 wt \% Sn bronze: Wear behaviour and microstructures. Wear 2007, 263, 830-841. [CrossRef]

8. Wang, J.; Zhou, X.L.; Li, J.; Brochu, M.; Zhao, Y.F. Microstructures and properties of SLM-manufactured Cu-15Ni-8Sn alloy. Addit. Manuf. 2020, 31, 100921. [CrossRef]

9. Liao, Y.; Xie, M.; Chen, H.; Xie, W.; Wang, H.; Yang, B. Thermodynamics and kinetics of discontinuous precipitation in Cu-9Ni-x Sn alloy. J. Alloys Compd. 2020, 827, 154314. [CrossRef]

10. Cheng, J.; Zhang, S.; Gan, X.; Li, Z.; Zhou, K. Wear regime and wear mechanism map for spark-plasma-sintered Cu-15Ni-8Sn$0.2 \mathrm{Nb}$ alloy under oil lubrication. J. Mater. Eng. Perform. 2019, 28, 4187-4196. [CrossRef]

11. Abboud, J.A.H.; Dwarakadasa, E.S. Modification of the spinodal hardening in a Cu- $9 \mathrm{wt} \% \mathrm{Ni}-6 \mathrm{wt} \% \mathrm{Sn}$ alloy by $0.1 \mathrm{wt} \%$ silicon or aluminium addition. J. Mater. Sci. Lett. 1983, 2, 233-235.

12. Schwartz, L.H.; Mahajan, S.; Plewes, J.T. Spinodal decomposition in a Cu-9 wt\% Ni-6 wt\% Sn alloy. Acta. Metall. 1974, 22, 601-609. [CrossRef]

13. Fan, J.; Liu, Z.; Zhai, H.; Wang, X.; Wang, Y.; Li, Y.; Zhou, X.; Wu, S.; Liu, J. Effect of Co content on the microstructure, spreadability, conductivity and corrosion resistance of Sn-0. 7 Cu alloy. Microelectron. Reliab. 2020, 107, 113615. [CrossRef]

14. Miki, M.; Ogino, Y. Effects of doped elements on the cellular precipitation in Cu-10 Ni-8 Sn alloy. Mater. Trans. JIM 1994, 35, 313-318. [CrossRef]

15. Gao, M.; Chen, Z.; Kang, H.; Li, R.; Wang, W.; Zou, C.; Wang, T. Effects of Nb addition on the microstructures and mechanical properties of a precipitation hardening Cu-9Ni-6 n alloy. Mater. Sci. Eng. A 2018, 715, 340-347. [CrossRef]

16. Ouyang, Y.; Gan, X.; Li, Z.; Zhou, K.; Zhang, S.; Jiang, Y.; Zhang, X. Microstructure evolution of a Cu- $15 \mathrm{Ni}-8 \mathrm{Sn}-0.8 \mathrm{Nb}$ alloy during prior deformation and aging treatment. Mater. Sci. Eng. A 2017, 704, 128-137. [CrossRef]

17. Ouyang, Y.; Gan, X.P.; Zhang, S.Z.; Li, Z.; Zhou, K.C.; Jiang, Y.X.; Zhang, X.W. Age-hardening behavior and microstructure of Cu-15Ni-8Sn-0.3Nb alloy prepared by powder metallurgy and hot extrusion. Trans. Nonferrous Met. Soc. China 2017, 27, 1947-1955. [CrossRef]

18. Lei, Q.; Li, Z.; Zhu, A.; Qiu, W.; Liang, S. The transformation behavior of Cu-8.0Ni-1.8Si-0.6Sn-0.15Mg alloy during isothermal heat treatment. Mater. Charact. 2011, 62, 904-911. [CrossRef]

19. Zhao, C.; Zhang, W.; Wang, Z.; Li, D.; Luo, Z.; Yang, C.; Zhang, D. Improving the mechanical properties of Cu-15Ni-8Sn alloys by addition of Titanium. Materials 2017, 10, 1038. [CrossRef] [PubMed]

20. Zheng, Z.; Guo, P.; Li, J.; Yang, T.; Song, Z.; Xu, C.; Zhou, M. Effect of cold rolling on microstructure and mechanical properties of a Cu-Zn-Sn-Ni-Co-Si alloy for interconnecting devices. J. Alloys Compd. 2020, 831, 154842. [CrossRef]

21. Wang, Y.; Qiu, X.M.; Sun, D.Q.; Yin, S.Q. Influence of Ti on microstructure and strength of c-BN/Cu-Ni-Sn-Ti composites. Int. J. Refract. Met. Hard Mater. 2011, 29, 293-297. [CrossRef]

22. Li, N.J.; Li, X.N.; Li, Z.M.; Yu, Q.X.; Zheng, Y.H.; Hu, Y.L.; Wang, Q.; Dong, C.; Jiang, Y.X.; Zhang, X.W. Differential effects of Zn and $\mathrm{Co}$ solutes on the properties of $\mathrm{Cu}-\mathrm{Ni}-\mathrm{Sn}$ alloys. Intermetallics 2020, 125, 106894. [CrossRef]

23. Guo, C.; Wan, J.; Chen, J.; Xiao, X.; Huang, H.; Liu, J.; Yang, B. Inhibition of discontinuous precipitation and enhanced properties of $\mathrm{Cu}-15 \mathrm{Ni}-8 \mathrm{Sn}$ alloy with Fe addition. Mater. Sci. Eng. A 2020, 795, 139917. [CrossRef]

24. Guo, C.; Chen, J.; Xiao, X.; Huang, H.; Wang, W.; Yang, B. The effect of Co addition on the modulated structure coarsening and discontinuous precipitation growth kinetics of $\mathrm{Cu}-15 \mathrm{Ni}-8 \mathrm{Sn}$ alloy. J. Alloys Compd. 2020, 835, 155275. [CrossRef]

25. Yang, D.H.; Kim, Y.K.; Park, S.H.; Lee, K.A. Improved mechanical and thermophysical properties of additively manufactured Cu-Ni-Sn-P alloy by using aging treatment. J. Alloys Compd. 2021, 875, 160050. [CrossRef]

26. Miki, M.; Ogino, Y. Effect of the addition of B and P on the cellular precipitation in Ni-Sn and Cu-Ni-Sn alloys. Nippon. Kinzoku Gakkaishi 1983, 47, 983-990.

27. Wang, N.; Shen, Y.; An, Q.; Reddy, K.M.; Jin, M.; Karre, R.; Wang, X. Microstructure evolution and mechanical property of Cu-15Ni-8Sn-0.2 Nb alloy during aging treatment. J. Mater. Sci. Technol. 2021, 86, 227-236. [CrossRef]

28. Zhao, C.; Wang, Z.; Li, D.; Pan, D.; Lou, B.; Luo, Z.; Zhang, W. Optimization of strength and ductility in an as-extruded $\mathrm{Cu}-15 \mathrm{Ni}-8 \mathrm{Sn}$ alloy by the additions of $\mathrm{Si}$ and Ti. J. Alloys Compd. 2020, 823, 153759. [CrossRef]

29. Jeon, W.S.; Shur, C.C.; Kim, J.G.; Han, S.Z.; Kim, Y.S. Effect of Cr on the corrosion resistance of Cu-6 Ni-4 Sn alloys. J. Alloys Compd. 2008, 455, 358-363. [CrossRef]

30. Yu, Q.X.; Li, X.N.; Wei, K.R.; Li, Z.M.; Zheng, Y.H.; Li, N.J.; Cheng, X.T.; Wang, C.Y.; Wang, Q.; Dong, C. Cu-Ni-Sn-Si alloys designed by cluster-plus-glue-atom model. Mater. Des. 2019, 167, 107641. [CrossRef]

31. Guo, Z.; Jie, J.; Liu, S.; Liu, J.; Yue, S.; Zhang, Y.; Li, T. Suppression of discontinuous precipitation in age-hardening Cu-15Ni-8Sn alloy by addition of V. J. Alloys Compd. 2020,813, 152229. [CrossRef]

32. Guo, Z.; Jie, J.; Liu, S.; Zhang, Y.; Qin, B.; Wang, T.; Li, T. Effect of V addition on microstructures and mechanical properties of Cu-15Ni-8Sn alloy. Mater. Sci. Eng. A 2019, 748, 85-94. [CrossRef]

33. Guo, Z.; Jie, J.; Liu, J.; Yue, S.; Liu, S.; Li, T. Effect of cold rolling on aging precipitation behavior and mechanical properties of $\mathrm{Cu}-15 \mathrm{Ni}-8 \mathrm{Sn}$ alloy. J. Alloys Compd. 2020, 848, 156275. [CrossRef]

34. Peng, G.; Gan, X. Re-aging behavior of $\mathrm{Cu}-15 \mathrm{Ni}-8 \mathrm{Sn}$ alloy pretreated by dynamic strain aging. Mater. Sci. Eng. A 2019, 752, 18-23. [CrossRef]

35. Li, J.; Ding, H.; Li, B. Study on the variation of properties of $\mathrm{Cu}-\mathrm{Cr}-\mathrm{Zr}$ alloy by different rolling and aging sequence. Mater. Sci. Eng. A. 2020, 802, 140413. [CrossRef] 
36. Liu, J.; Wang, X.; Chen, J.; Liu, J. The effect of cold rolling on age hardening of Cu-3Ti-3Ni-0.5 Si alloy. J. Alloys Compd. 2019, 797, 370-379. [CrossRef]

37. Guo, C.; Shi, Y.; Chen, J.; Xiao, X.; Liu, B.; Liu, J.; Yang, B. Effects of P addition on spinodal decomposition and discontinuous precipitation in Cu-15Ni-8Sn alloy. Mater. Charact. 2021, 171, 110760. [CrossRef] 